\title{
Pengembangan Materi Ajar Seni Budaya Sub Materi Musik pada Sekolah Umum Jenjang Pendidikan Dasar
}

\author{
Wadiyo \\ Sendratasik FBS Universitas Negeri Semarang \\ wadiyo@mail.unnes.ac.id \\ Udi Utomo \\ Sendratasik FBS Universitas Negeri Semarang \\ udiutomo@mail.unnes.ac.id
}

\begin{abstract}
Pendidikan Dasar di Indonesia memberikan mata pelajaran seni budaya yang di dalamnya tercakup materi musik. Pendidikan Dasar tingkat Sekolah Dasar pada kurikulum 2013 edisi revisi 2016 pembelajarannya diubah dalam bentuk pembelajaran tematik namun demikian musik tetap digunakan sebagai alat pendidikan. Untuk tingkatan Sekolah Menengah Pertama tetap menggunakan nama mata pelajaran seni budaya yang di dalamnya tercakup materi musik.Tujuan penelitian ini adalah untuk mengetahui bagaimana kebutuhan dan pengembangan materi ajar seni budaya sub materi musik untuk Pendidikan Dasar SD dan SMP. Metode penelitian yang diterapkan adalah research development. Lokasi penelitian, Kota dan Kabupaten Semarang. Teknik pengumpulan data dilakukan melalui observasi, wawancara, dan studi dokumentasi. Teknik keabsahan data menggunakan treangulasi data. Teknik analisis data menggunakan alur analisis interaktif. Hasil penelitian menunjukkan, materi ajar seni budaya sub materi musik dalam praktik pembelajarannya dikembangkan oleh setiap guru. Secara menonjol para guru Sekolah Dasar selalu mengganti lirik lagu yang sudah ada diganti dengan lirik materi pelajaran untuk memasukkan pesan pendidikan yang diinginkan oleh guru. Untuk Sekolah Menengah Pertama membutuhkan media-media tentang musik lokal dan atau daerah serta media-media yang berhubungan dengan musik diatonis, baik untuk teknik vokal atau permainan instrumen.
\end{abstract}

Kata kunci: musik lokal; musik daerah; pentatonik; diatonik; vokal.

\section{Pendahuluan}

Bicara pengembangan materi ajar seni budaya sub materi musik pada Sekolah Umum jenjang Pendidikan Dasar tidak akan lepas dari adanya kurikulum sekolah yang akhir-akhir ini selalu berubah dan atau disempurnakan terus. Pergantian kurikulum sekolah secara periodik tampaknya tidak bisa dihindari dan selalu ada untuk menghadapi dan mengantisipasi perubahan jaman dan atau untuk menggapai tujuan yang diinginkan oleh bangsa. Pendidikan Dasar sebagai fondasi pendidikan yang dipikirkan dapat meletakkan dasar-dasar pendidikan sejak awal menjadi perhatian yang sangat serius. Kegalauan akan kegagalan pendidikan yang bersumber dari kurikulum menjadi alasan utama untuk mengubah dan atau menyempurnakan kurikulum yang telah dilaksanakan.

Pendidikan seni budaya sub materi musik untuk Pendidikan Dasar tidak lepas dari rangkaian perubahan atau penyempurnaan kurikulum yang umum itu. Sekalipun demikian, segala bentuk perubahan kurikulum yang ada, untuk materi seni budaya sub materi musik tidak ada perubahan yang berarti dan bahkan boleh dibilang materinya selalu sama, yakni berkait 
dengan vokal atau seni suara, instrumen atau alat musik, dan campuran antara musik vokal dan instrumen. Apa yang menjadi kebutuhan sekolah berkait dengan hadirnya kurikulum itu dan bagaimana pengembangan materi ajarnya, menjadi perhatian peneliti untuk usaha memahami dan usaha membantu tercapinya tujuan hakiki dari diberikannya pendidikan seni itu di Sekolah Umum utamanya jenjang Pendidikan Dasar SD dan SMP.

Beberapa penelitian terdahulu berkait dengan pembelajaran musik di Sekolah Umum jenjang Pendidikan Dasar yang telah ada, yaitu Sekolah Dasar dan Sekolah Menengah Pertama dikaji oleh peneliti untuk dijadikan dasar atau pijakan pengembangan lebih lanjut. Penelitian terdahulu yang dikaji oleh peneliti yang pertama adalah penelitian yang dilakukan oleh Udi Utomo dan Syahrul Syah Sinaga (2009) yang dimuat dalam jurnal seni Harmonia. Masalah yang diangkat dalam penelitian itu berkait dengan kendala guru untuk menjadikan pembelajaran seni musik berbasis budaya yang berkonteks kreatif, kecakapan hidup, dan menyenangkan untuk siswa Sekolah Dasar dan Madrasah Ibtidaiyah dapat tercapai. Metode penelitian yang diterapkan adalah research and development yang menggunakan subjek guru, kepala sekolah, dan ahli musik. Temuan penelitianya adalah kurangnya guru dalam hal (1) memahami isi kurikulum tentang musik, (2) memanfaatkan potensi anak untuk pengembangan musik, (3) mengembangkan metode pembelajaran musik, (4) mengembangkan sarana dan media pembelajaran musik, (5) memanfaatkan potensi lingkungan, dan (6) mengembangkan bentuk evaluasi.

Hasil penelitian terdahulu selanjutnya yang dikaji untuk mendasari penelitian ini adalah sebuah penelitian di Sekolah Dasar yang dilakukan oleh Herwin Yoga Wicaksono yang dimuat dalam jurnal Cakrawala Pendidikan (2009). Masalah yang diangkat dalam penelitian ini berkait dengan apakah kreativitas pembelajaran musik yang dilakukan oleh guru dapat meningkatkan minat siswa dalam mengikuti pelajaran musik. Metode penelitian yang diterapkan adalah kuantitatif dengan pendekatan kuasi eksperimen. Dalam penelitian ini yang dieksperimenkan adalah kreativitas guru dalam pembelajaran musik dengan upaya capaian untuk meningkatkan minat siswa dalam mengikuti pelajaran musik. Hasil penelitian menunjukkan, kreativitas pembelajaran yang dilakukan oleh guru signifikan meningkatkan minat siswa dalam mengikuti pelajaran musik. Kreativitas yang dilakukan guru dalam mengajar adalah sebuah kreativitas yang berhubungan dengan dorongan untuk menjadikan siswa tumbuh kebebasan dalam berimajinasi dan berekspresi seni musik.

Kajian penelitian untuk tingkatan Sekolah Menengah Pertama juga dilakukan untuk mendasari penelitian ini, utamanya yang berkait dengan upaya peningkatan hasil belajar musik. Penelitian ini dilakukan oleh Ekaningtyas Herminingrum dan Totok Sumaryanto yang dimuat dalam jurnal seni musik Universitas Negeri Semarang (2013). Masalah yang diangkat dalam penelitian itu adalah berkait dengan bagaimana meningkatkan aktivitas dan hasil belajar apresiasi musik Nusantara melalui penggunaan lagu model pada siswa kelas 8A SMPN 1 Pangkah Kabupaten Tegal. Jenis penelitian yang diterapkan dalam penelitian ini adalah tindakan kelas dengan menggunakan dua siklus dengan tiap siklusnya peneliti menggunakan lagu model yang berbeda. Teknik pengambilan data dilakukan dengan observasi, dokumentasi, tes, dan kuesioner.

Berdasar masalah dan cara penelitian yang dilakukan dalam penelitian itu dapat dilihat hasilnya bahwa, melalui pembelajaran yang menggunakan lagu model lagu daerah Nusantara ternyata dapat meningkatkan aktivitas belajar bernyanyi lagu daerah Nusantara dan meningkatkan kemampuan apresiasi para siswa terhadap lagu-lagu daerah Nusantara. Prasiklus melalui tes dan kuesioner berkait dengan aktivitas belajar dan kemampuan apresiasi menunjukkan angka 16,7\% yang dilihat dalam penelitian ini sebagai sebuah kriteria yang rendah. Usai siklus pertama, hasil belajar berkait 
permasalahan yang diangkat meningkat menjadi 53\% dan melalui pembenahan siklus kedua, hasil belajarnya meningkat mendapatkan angka $83,7 \%$. Disimpulkan, lagu model merupakan media yang penting untuk dijadikan media pembelajaran dalam hubungannya untuk meningkatkan aktivitas belajar musik dan atau lagu serta dapat digunakan untuk meningkatkan kemampuan apresiasi para siswa terhadap lagu yang diajarkan oleh guru.

Kajian penelitian untuk penelitian pada Pendidikan Dasar jenjang Sekolah Menengah Pertama sebagai penelitian terdahulu yang juga dikaji dalam penelitian ini adalah berkait dengan masalah upaya meningkatkan minat dan hasil belajar membaca not balok melalui media pembelajaran sibelius pada siswa kelas VII Sekolah Menengah Pertama Negeri IV Ungaran Kabupaten Semarang. Penelitian ini dilakukan oleh Trias Radika dan Totok Sumaryanto yang dimuat dalam jurnal Seni Musik (2013). Jenis penelitian yang diterapkan adalah penelitian tindakan kelas dengan menerapkan langkah dua siklus. Langkah yang dilakukan untuk mencari data sampai pada hasil yang didapat menggunakan cara observasi, wancara, dokumentasi, angket, kuesioner, dan unjuk kerja sebagai sebuah tindakan dari prasiklus sampai siklus akhir.

Akhir penelitian sebagai hasil menunjukkan bahwa, dengan diterapkannya media pembelajaran yang menggunakan program sibelius dapat meningkatkan minat membaca not balok dan hasil belajar membaca notasi balok. Prasiklus menunjukkan angka 6\% sebagai kriteria minat rendah untuk belajar membaca not balok dan begitu pula kemampuan membaca not balok dari siswa seluruh kelas. Melalui tindakan kelas yang dilakukan oleh peneliti menghasilkan, siklus pertama menghasilkan peningkatan minat belajar not balok dari $6 \%$ menjadi $62 \%$ dan siklus dua menunjukkan angka $72 \%$. Untuk hasil belajar kemampuan membaca not balok yang dari prasiklus hanya menunujukkan angka $6 \%$, akhirnya melalui tindakan siklus pertama menunjukkan peningkatan dari prasiklus yang
6\% dapat menjadi $76.6 \%$ dan siklus kedua dengan dilakukan beberapa perubahan berkait dengan penggunaan program sibelius meningkatkan angka kemampuan menjadi 79\%. Melihat hasil tersebut tampaknya program sibelius yang diterapkan oleh guru sebagai metode untuk meningkatkan minat untuk bisa membaca dan menulis not balok serta upaya meningkatkan kemampuan membaca not balok dilihat sebagai berhasil.

Berdasar latar belakang masalah yang dikemukakan berkait dengan muatan kurikulum yang menempatkan seni musik dijadikan sub bahan ajar dari pelajaran seni budaya di Sekolah Umum jenjang Pendidikan Dasar serta kajian penelitian terdahulu yang dijadikan pijakan dasar dalam penelitian ini, dapat dilihat banyak hal baik secara kualitatif ataupun kuantatif apa-apa yang masih harus diketahui dan dikembangkan dalam pembelajaran seni budaya sub materi musik pada Sekolah Umum jenjang Pendidikan Dasar tingkat Sekolah Dasar dan Sekolah Menengah Pertama. Ini merupakan gap anatara permasalahan-permasalahan penelitian terdahulu yang telah dikaji dengan permasalahan penelitian yang dilakukan oleh penulis saat ini. Berkait dengan itu dapat disampaikan tujuan pokok dari penelitian ini secara mendasar, yakni untuk:

(1) Mengetahui kebutuhan dan pengembangan materi ajar seni budaya sub materi musik pada jenjang pendidikan Sekolah Dasar.

(2) Mengetahui kebutuhan dan pengembangan materi ajar seni budaya sub materi musik pada jenjang pendidikan Sekolah Menengah Pertama.

Konsep dan atau teori yang digunakan untuk membahas permasalahan lapangan adalah konsep dan atau teori yang berkait dengan kebutuhan pengembangan musik dan konsep pembelajaran seni musik di Sekolah Umum Jenjang Sekolah Dasar dan Sekolah Menengah Pertama. Musik dilihat sebagai seni suara yang mengekspresikan ide-ide dan perasaan-perasaan dalam bentuk-bentuk yang signifikan melalui elemen-elemen ritme, melodi, harmoni, dan warna. Bentuk musik dapat dibedakan atas tiga 
macam, yaitu musik vokal, musik instrumental, dan musik campuran. Musik vokal, adalah musik yang dinyanyikan dengan suara manusia. Musik instrumental, adalah musik yang dilagukan dengan alat-alat musik. Musik campuran, adalah perpaduan antara suara manusia dengan musik instrumental yang dihidangkan bersama-sama (Humpreys, 2010: 126).

Pengembangan materi ajar seni musik di Sekolah Umum erat kaitannya dengan bagaimana musik itu diwujudkan dalam rangka penggunaanya sebagai media atau alat pendidikan. Alat pendidikan sebagaimana digariskan dalam kurikulum adalah untuk alat pendidikan apresiasi dan kreasi. Apresiasi adalah suatu pengenalan seni melalui perasaan dan kepekaan batin terhadap seni yang diperkenalkan sampai kememahami serta mengakui terhadap nilai-nilai keindahan yang diungkapkan dalam karya seni tersebut. Silverman (2013) lebih lanjut menjelaskan bahwa, apresiasi merupakan proses pengenalan dan pemahaman nilai karya seni, untuk menghargainya, dan menafsir makna yang terkandung di dalamnya.

Kehadiran apresiasi akan memunculkan kreativitas dari apresiator. Tumbuhnya kreativitas seni yang demikian menurut Sumaryanto (2002) akan berpengaruh terhadap pengembangan proses kreatif pada bidang lainnya. Menurut Triana (2005), pendidikan kreasi yang dilakukan di sekolah perlu dilakukan melalui aktivitas siswa, yakni siswa dituntut untuk melakukan aktivitas berkarya seni apapun hasilnya. Pada tahap ini, siswa dilatih kepekaan indranya, daya imajinasinya, dan pengamatan untuk menciptakan karya, mengidentifikasi, melakukan eksperimen, dan mengorganisasikan elemen-elemen seni. Dalam hubungannya dengan apresiasi dan kreasi seni musik yang dijadikan sebagai alat pendidikan seni di Sekolah Umum, perlu dikembangkan elemen-elemen bentuk karya seni musik itu yang harus dikenal oleh anak didik.

\section{Metode Penelitian}

Penelitian ini menggunakan pendekatan penelitian pengembangan yang biasa disebut dengan Research and Development, yakni penelitian yang pada akhir penelitiannya nanti harus menghasilkan buah produk yang berangkat dari hasil yang didapat dari pemetaan kebutuhan lapangan. Penelitian ini lebih banyak mengadopsi dan mengembangkan dari apa yang telah dikembangkan oleh Yoshikawa (2012); Organisation for Economic Co-Operation and Development (2002); Briggs \& Wager (1992); Bogdan \& Biklen (1982); dan Borg \& Gall (1983). Namun demikian karena penelitian ini masih dalam taraf awal, maka peneliti masih akan melihat kebutuhan lapangan yang berkait dengan bagaimana materi ajar itu dikembangkan dalam suatu proses belajar mengajar oleh guru.

Lokasi dan subjek penelitian, sasaran penelitian, dan langkah sebagai cara penelitian yang dilakukan, dapat dikemukakan berikut ini.

\section{Lokasi dan Subjek Penelitian}

Lokasi penelitian ini adalah Kota Semarang dan Kabupaten Semarang, dengan subjek penelitian para guru dan peserta didik pendidikan dasar Sekolah Dasar dan Sekolah Menengah Pertama. Sekolah Dasar yang dijadikan subjek penelitian adalah SDN Sekaran 1, SDN Sekaran 2, SDN Mangunsari, dan SD Hj. Isriati 1 Kota Semarang. SMP yang dijadikan subjek penelitian adalah SMPN 2 Ambarawa dan SMP Islam Sudirman Ambarawa Kabupaten Semarang dan SMPN 25 Kota Semarang.

\section{Sasaran Kajian dalam Penelitian}

Sasaran kajian dalam penelitian ini berkait dengan pengembangan materi ajar seni budaya sub materi musik untuk siswa Pendidikan Dasar SD dan SMP dengan rincian pertama, berhubungan dengan bagaimana kebutuhan yang dirasakan oleh sekolah umum jenjang pendidikan dasar SD dan SMP dalam hubungannya dengan materi ajar musik dan pelaksanaannya dalam pembelajaran. Kedua, Bagaimana materi ajar seni musik dikembangkan oleh pengajar sesuai tuntutan yang harus dicapai dalam pendidikan seni di sekolah.

\section{Langkah Penelitian}

Langkah penelitian ini melalui proses sebagaimana yang biasa dilakukan oleh Yoshikawa (2012) dan Borg \& Gall (1983) yang 
mengemukakan bahwa, secara mendasar prosedural penelitian pengembangan dapat dilakukan dengan tahap-tahap yang bisa dikembangkan seperti pertama, pengumpulan data dalam kaitannya untuk memetakan kebutuhan lapangan. Kedua, dilakukan sebuah perencanaan lebih lanjut setelah dilakukannya pemetaan kebutuhan lapangan. Untuk melihat kebutuhan lapangan dan bagaimana kebutuhan lapangan saat ini dikembangkan dalam suatu proses belajar mengajar oleh guru, peneliti melakukan observasi, wawancara, dan melihat dokumentasi yang dilakukan dalam proses belajar mengajar.

Berangkat dari data lapangan yang didapat dari hasil observasi, wawancara, dan studi dokumentasi oleh peneliti direduksi, disajikan dalam bentuk deskriptif analitik, dan diverifikasi sebagaimana yang umum sering digunakan dalam sebuah penelitian kualitatif. Sekalipun jenis penelitian ini merupakan jenis penelitian pengembangan yang luarannya harus menghasilkan buah produk tetapi untuk tahap ini hasil penelitiannya belum sampai pada pembuatan produk selain identifikasi kebutuhan lapangan dan pelukisan apa yang dikembangkan saat ini di lapangan. Oleh karena itulah cara-cara penelitian kualitatif digunakan dalam penelitian ini.

Dalam hubungannya untuk melihat keterpercayaan dan atau keabsahan data maka dalam observasi, peneliti dibantu oleh anggota penelitian dan yang diobservasi ada beberapa sekolah. Begitu pula dalam wawancara dan mencari data dokumentasi, peneliti dibantu juga oleh anggota tim dan beberapa tenaga bantuan lainnya. Teknik treangulasi data diterapkan dengan cara mencocokkan data hasil dari observasi, wawancara, studi dokumentasi. Seluruh data yang didapat dianalisis menggunakan model interaktif yang selalu diinterpretasi oleh peneliti agar antara etik emiknya selalu berjalan bersama.

\section{Hasil Penelitian}

Pada bagian ini disampaikan hasil penelitian dan pembahasan. Hasil penelitian untuk Sekolah Dasar dan Sekolah Menengah Pertama disajikan secara terpisah, namun untuk pembahasannya dilakukan secara menyatu sebab keduanya memiliki keterkaitan yang tidak bisa dipisahkan.

\section{Hasil Penelitian tentang Kebutuhan dan Pengembangan Seni Musik di SD}

Berdasar data lapangan diketahhui bahwa, saat ini Sekolah Dasar menerapkan kurikulum 2013 edisi revisi 2016. Kurikulum ini menerapkan pembelajaran tematik, yakni pembelajaran yang dilaksanakan atas tema-tema yang telah ditentukan oleh kurikulum. Materi pelajaran atau mata ajar apapun harus bermuara pada tema-tema yang digunakan pada hari dan jam tatap muka itu. Intinya lalu tema tersebut didekati menggunakan berbagai bidang mata ajar yang seni budaya sub materi musik menjadi pilihan yang biasa digunakan untuk menyampaikan pesan atau isi berkait dengan tema-tema itu. Berikut tema-tema itu yang disajikan mulai kelas l sampai dengan kelas Vl.

\begin{tabular}{l}
\hline Kelas 1 \\
Tema pembelajarannya adalah tentang Diriku, \\
Kegemaranku, Kegiatanku, Keluargaku, \\
Pengalamaku, Lingkungan Bersih, Sehat, dan \\
Asri, Benda, Hewan, dan Tanaman di Sekitarku, \\
serta Peristiwa Alam. \\
Kelas ll \\
Tema pembelajarannya adalah tentang Hidup \\
Ruku, Bermain di Lingkunganku, Tugasku \\
Sehari-hari, Hidup Bersih dan Sehat, Aku dan \\
Sekolahku, Air, Bumi, dan Matahari, Merawat \\
Hewan dan Tumbuhan, serta Keselamatan di \\
Rumah dan di Perjalanan. \\
\hline Kelas 11l tentang \\
Tema pembelajarannya adalah \\
Pertumbuhan dan Perkembangan Makhluk \\
Hidup, Menyayangi Tumbuhan dan Hewan \\
Sekitar, Benda di Sekitarku, Hak dan \\
kwajibanku, Perubahan Cuaca, Energi dan \\
perubahannya, Perkembangan dan teknologi, \\
dan Praja Muda Karana. \\
Kelas IV \\
Tema pembelajarannya adalah tentang Indahnya \\
kebersamaan, Selalu Berhemat Energi, Peduli \\
Terhadap Makhluk Hidup, Berbagai Pekerjaan, \\
Pahlawanku, Indahnya Negeriku, Cita-citaku, \\
\hline
\end{tabular}




Tempat Tinggalku, dan Makanan Sehat dan
Bergizi.
Kelas V
Tema pembelajarannya adalah tentang Organ
gerak Hewan dan Manusia, Udara Bersih,
Makanan Sehat, Organ Peredaran Darah,
Ekosistem, Kalor dan Perpindahannya, Benda-
benda di Sekitar, Peristiwa dalam Kehidupan,
dan Lingkungan Sahabat Kita.
Kelas V1 pembelajarannya adalah tentang
Tema Meman
Selamatkan Makhluk Hidup, Persatuan dalam
Perbedaan, Tokoh dan Penemuan, Globalisasi,
Wirausaha, Menuju Masyarakat Sehat,
Kepemimpinan, Bumiku, dan Menjelajah
Angkasa Luar.

Berdasar atas dasar tema-tema itu, temuan dalam penelitian ini adalah, para guru kesulitan menggunakan materi musik yang pesan musik itu berkait dengan tema yang diajarkan dalam hari-hari. Pada akhirnya para guru menggunakan lagu-lagu yang sudah dikenal oleh mayoritas murid, lalu syair atau lirik lagu diganti sesuai isi atau pesan pendidikan yang ada pada tema tersebut. Kondisi ini bisa dilihat sebagai bentuk pengembangan lagu tetapi sebetulnya mengganti syair lagu yang tidak sesuai dengan lagu aslinya adalah sebuah pelanggaran hak cipta, apalagi bila itu sampai dikomersialkan. Selain itu syair yang asli dalam lagu tersebut menjadi tidak dikenal lagi oleh para murid sebab syairnya oleh guru sudah diganti dengan syair baru untuk menyampaikan pesan pendidikan dalam hubungannya dengan isi pelajaran. Untuk itulah jelaslah bahwa, sekolah sangat membutuhkan banyak lagu yang pesan atau isi lagunya sesuai dengan materi ajar atas seluruh tema-tema pembelajaran Sekolah Dasar mulai kelas 1 sampai dengan kelas $\mathrm{Vl}$.

\section{Hasil Penelitian tentang Kebutuhan dan Pengembangan Seni Musik di SMP}

Kebutuhan dan pengembangan materi ajar seni budaya sub materi musik yang ada pada Pendidikan Dasar jenjang Sekolah Menengah Pertama, berhubungan dengan materi-materi apa saja yang diajarkan di sekolah. Tidak berbeda dengan Sekolah Dasar, untuk Sekolah Menengah
Pertama juga menggunakan pijakan kurikulum 13 edisi revisi 2016 yang tiap kelas materi pembelajarannya berikut ini.

Kelas Vll

\begin{tabular}{|c|c|c|}
\hline $\begin{array}{l}\text { Materi } \\
\text { Pembelajaran }\end{array}$ & $\begin{array}{l}\text { Materi } \\
\text { Pembelajaran }\end{array}$ & $\begin{array}{l}\text { Materi } \\
\text { Pembelajaran }\end{array}$ \\
\hline Kelas Vll & Kelas V1ll & Kelas Xl \\
\hline $\begin{array}{l}\text { - Konsep } \\
\text { dasar } \\
\text { bernya-nyi } \\
\text { satu suara } \\
\text { (unisono) } \\
\text { secara } \\
\text { berkelompo } \\
\text { k. } \\
\text { - Teknik } \\
\text { bernyanyi } \\
\text { satu suara } \\
\text { secara } \\
\text { berkelom- } \\
\text { pok. }\end{array}$ & $\begin{array}{l}\text { Lagu daerah } \\
\text { setempat atau } \\
\text { daerah lain. } \\
\text { - Teknik } \\
\text { menyanyi } \\
\text { lagu daerah. }\end{array}$ & $\begin{array}{l}\text { - Pengembanga } \\
\text { n melodi lagu } \\
\text { untuk vokal/ } \\
\text { lagu tunggal. } \\
\text { - Teknik/ cara } \\
\text { mengem- } \\
\text { bangkan } \\
\text { Melodi lagu. }\end{array}$ \\
\hline $\begin{array}{l}\text { - Konsep } \\
\text { dasar } \\
\text { bernya-nyi } \\
\text { dalam dua } \\
\text { suara atau } \\
\text { lebih secara } \\
\text { berke- } \\
\text { lompok. } \\
\text { - Teknik } \\
\text { bernyanyi } \\
\text { de-ngan } \\
\text { dua suara } \\
\text { atau lebih } \\
\text { dalam } \\
\text { bentuk ke- } \\
\text { lompok } \\
\text { vokal. }\end{array}$ & $\begin{array}{l}\text { - Teknik } \\
\text { menyanyika } \\
\text { n lagu } \\
\text { daerah } \\
\text { dengan dua } \\
\text { suara. }\end{array}$ & $\begin{array}{l}\text { - Teknik/ } \\
\text { cara } \\
\text { mengem- } \\
\text { bangkan } \\
\text { melodi lagu } \\
\text { dalam } \\
\text { bentuk } \\
\text { kelom-pok } \\
\text { vokal. }\end{array}$ \\
\hline $\begin{array}{l}\text { - Konsep } \\
\text { dasar } \\
\text { permai-nan } \\
\text { alat musik } \\
\text { seder-hana } \\
\text { secara } \\
\text { perora- } \\
\text { ngan. } \\
\text { - Teknik } \\
\text { memainka } \\
\text { n alat } \\
\text { musik } \\
\text { sederhana }\end{array}$ & $\begin{array}{l}\text { - Teknik } \\
\text { memainkan } \\
\text { alat musik } \\
\text { tradisional } \\
\text { secara } \\
\text { perorangan. }\end{array}$ & $\begin{array}{l}\text { - Sajian lagu } \\
\text { atau musik } \\
\text { populer } \\
\text { secara } \\
\text { perora-ngan. }\end{array}$ \\
\hline
\end{tabular}




\begin{tabular}{|c|c|c|}
\hline $\begin{array}{l}\text { secara } \\
\text { perorangan }\end{array}$ & & \\
\hline $\begin{array}{l}\text { - Musik } \\
\text { ansambel } \\
\text { sejenis dan } \\
\text { campuran. } \\
\text { - Teknik } \\
\text { memainka } \\
\text { n an- } \\
\text { sambel } \\
\text { musik } \\
\text { sejenis dan } \\
\text { campuran. }\end{array}$ & $\begin{array}{l}\text { - Teknik } \\
\text { memainkan } \\
\text { alat musik } \\
\text { tradisional } \\
\text { secara } \\
\text { berkelompo } \\
\text { k. } \\
\text { - }\end{array}$ & 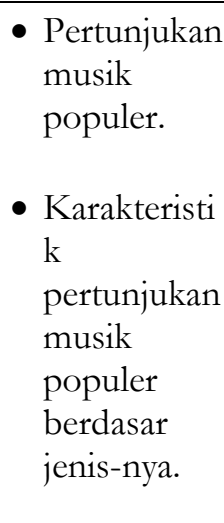 \\
\hline
\end{tabular}

Apa yang telah didapat melalui pencarian data di lapangan, ada beberapa pokok materi yang dilihat sebagai kebutuhan lapangan dan bisa dilihat juga bagaimana sekolah mengembangkan materi ajar sesuai dengan situasi kondisi di tiap sekolah yang dijadikan subjek penelitian. Kebutuhan sekolah untuk tingkat Sekolah Menengah Pertama ini adalah sebuah pengetahuan tentang musik lokal atau musik daerah dan musik diatonis. Apa yang dilihat di lapangan, para guru banyak mengajarkan musik lokal daerah menggunakan ideom musik diatonis. Untuk pembelajaran musik diatonis, tidak semua guru memiliki kecakapan terhadap musik diatonis tentang vokal dan permainan instrumen.

Pengembangan materi ajar yang dijalankan dalam proses belajar mengajar secara inti dapat dilihat bahwa, musik lokal dan atau daerah yang mestinya diajarkan menggunakan tangganda pelog dan slendro namun oleh para guru banyak dilagukan dan atau dimainkan menggunakan nada-nada diatonis. Ini sebetulnya bisa dilihat sebagai pengembangan materi ajar, sayangnya bagaimana sebetulnya musik lokal atau daerah itu yang sebenarnya, tidak dipahami. Dampaknya para siswa tidak mendapatkan materi musik lokal atau daerah yang diinginkan oleh kurikulum. Ini terjadi di sekolah yang pengajarnya berlatar belakang musik diatonis. Untuk sekolah yang latar belakang guru atau pengajarnya musik pentatonis juga demikian halnya. Ideom-ideom musik lokal atau daerah yang dikuasai oleh guru atau pengajar digunakan untuk berkesenian musik diatonis. Ini juga sebetulnya bisa dilihat sebagai bentuk pengembangan materi ajar namun sayangnya menjadikan para siswa tidak mendapat pengetahuan dan keterampilan sebagaimana mestinya.

3. Pembahasan tentang Kebutuhan dan Pengembangan Materi Ajar Musik di Sekolah Dasar dan Sekolah Menengah Pertama.

Kebutuhan sekolah umum utamanya tingkatan Pendidikan dasar SD dan SMP berkait dengan musik adalah sesuatu yang tidak bisa dihindarkan dan memang harus demikian. Berkait dengan itu sebagaiman dikemukakan oleh Fitriani yang dimuat dalam jurnal Resital (2014) bahwa, sekalipun guru dominan dalam memberikan pelajaran pada siswa namun pembelajaran seni musik di Sekolah Umum seharusnya lebih difokuskan pada keterlibatan para siswa. Hal ini dapat dilakukan dengan caracara seperti bernyanyi bersama, bermain dengan ritme atau irama, bergerak mengikuti irama, sampai berkreasi musikal. Dengan cara demikian para siswa akan banyak dapat hal. Musik merupakan bentuk seni yang banyak fungsinya untuk perkembangan fisik, mental, jasmani, rokhani, kecerdasan logika, kecerdasan emosi, kecerdasan spiritual, dan berbagai kecerdasan lain yang harus dimiliki oleh anak menuju pada kesempurnaan kedewasaannya.

Berkait dengan kebutuhan Sekolah Dasar akan lagu yang digunakan untuk menyampaikan pesan pendidikan atau materi ajar adalah wajar sebab otak manusia secara radikal terbagi kanan dan kiri. Otak kanan didominasi oleh rasa sedangkan otak kiri cenderung didominasi oleh logika. Oleh karena itu dilihat sebagai sangat penting dan fondamental olah rasa melalui musik berupa lagu dilakukan, yang ini tidak sekedar untuk olah rasa semata namun demikian juga sangat berguna untuk membantu olah kecerdasan seperti kecerdasan logika dan juga olah kecerdasan spiritual, dan lain-lain yang semua itu bisa 
melalui proses apresiasi dan kreasi (Sumaryanto, 2002; Triana, 2005; Silverman, 2013). Dalam hubungan dengan itu mnurut Tyasrinestu (2014) melalui menyanyikan lagu, anak akan berpengalaman dalam hal seperti mengikuti pola ritme, pola melodi yang diulang, dan pola kata yang diulang. Itu semau akan menjadikan banyak makna dari musik yang didapat oleh siswa termasuk memahami pesan lirik.

Melalui lagu berlirik dolanan misalnya, akan dapat membantu karakter jiwa anak mengenal diri dan lingkunganya (Rosmiati, 2014). Melalui musik atau lagu segala sesuatu pesan yang ada di dalam musik atau lagu dapat masuk keanak didik melalui rasanya. Ini bisa dilakukan melalui proses kegiatan bermusik atau bernyanyi. Melalui bermusik atau bernyanyi atau mendengarkan musik atau nyanyian, tidak ada sesuatu pengetahuan yang dipaksakan kepada anak didik. Semua akan berjalan dengan sendirinya dan atau apa adanya secara alami. Inilah gunanya atau pentingnya musik atau lagu digunakan untuk menyampaikan pesan pendidikan. Dalam hubungan dengan bagaimana kurikulum sekolah umum menekankan pentingnya musik dalam bentuk lagu digunakan sebagai sebuah pendekatan untuk memasukkan materi ajar dapat dipahami.

Kesulitan yang menghadang para pengajar di Sekolah Umum utamanya para guru Sekolah Dasar adalah bagaimana isi pelajaran sebagai materi ajar harus dituangkan ke dalam bentuk lagu yang sekiranya lagu itu dapat menyenangkan anak didik. Ini adalah sebuah permasalahan yang perlu dicari solusinya. Sebenarnyalah tidak ada orang normal yang tidak senang dengan musik atau lagu dan tidak bisa bermusik atau berlagu. Kesenangan itu bisa dipadukan dengan akal pikiran dan dituangkan dalam bentuk nyanyian. Nyanyian tidak harus berupa lagu utuh sebagaimana lagu-lagu umum, namun untuk kepentingan memasukkan materi ajar ini bisa sekenanya yang penting diekspresikan atau diuangkap dalam nada dan irama. Dikemukakan Humpreys (2010) paduan nada dan irama akan membentuk melodi, yang dari melodi itu diisi kata sebagai isi materi ajar yang dalam musik atau lagu itu dilihat sebagai pesan lagu.

Atas dasar pemikiran itulah sebetulnya tidak ada guru atau pendidik atau pengajar yang tidak bisa mencipta lagu atau menuangkan materi ajar lewat lagu yang dicipta sendiri. Mengapa demikian sebab lagu atau nyanyian bisa berupa apapun yang ada pada benak guru yang berkait dengan isi pelajaran atau materi ajar yang harus disampaikan kepada murid. Apa yang dikembangkan oleh guru selama ini yang memasukkan materi ajar lewat nyanyian dengan cara mengganti syair atau lirik lagu yang telah ada, sedikit demi sedikit bisa dihilangkan. Mengapa cara ini harus dihilangkan karena sebetulnya cara ini adalah sebuah pelanggaran hak cipta jika sampai itu dikomersialkan dengan dampak yang merugikan mereka yang mencipta sebab lagu itu terus berubah pesan dan atau maknanya.

Cara penggunaan lagu sebagai sebuah pendekatan pembelajaran untuk memasukkan pesan pendidikan atau isi dari sebuah pelajaran bisa melalui cara apresiasi ataupun kreasi. Namun demikian cara apresiasi aktif dan pasif, yakni menirukan nyanyian dan menikmati nyanyian, seseorang akan dapat menangkap pesan dari lagu tersebut secara lebih mudah. Apresiasi musik adalah penghargaan yang didapat bisa dari proses mendengarkan, menirukan, memahami, menginterpretasi, dan atau mengevaluasi atau menilai. Sedangkan kreasi adalah membuat sesuatu yang baru yang kadang merupakan bentuk dari hasil apresiasi terhadap sesuatu yang diwujudkan dalam bentuk baru.

Tidaklah mudah bagi para guru untuk mendapatkan lagu yang dapat membantu menyampaikan pesan pendidikan sesuai dengan tema pembelajaran yang telah ditetapkan dalam kurikulum. Oleh karena itu para guru melakukan kreativitas dengan cara menggunakan lagu lagu yang sudah ada dan atau lagu-lagu yang sudah dikenal oleh para siswa dengan cara lirik lagunya diganti dengan pesan pendidikan yang sesuai dengan tema pembelajaran. Dengan cara itulah ketentuan dalam kurikulum yang mewajibkan 
setiap tema harus disampaikan dengan berbagai pendekatan pembelajaran termasuk dengan kegiatan bernyanyi dapat dilakukan.

Musik atau lagu merupakan bentuk seni suara yang mengekspresikan ide-ide dan perasaan-perasaan dalam bentuk-bentuk yang signifikan melalui elemen-elemen ritme, melodi, harmoni, dan warna. Bentuk musik dapat dibedakan atas tiga macam, yaitu musik vokal, musik instrumental, dan musik campuran dalam konteks pembelajaran tematik di Sekolah Dasar dalam hubungannya pula dengan memasukkan materi lewat bernyanyi atau nyanyian menggunakan lagu-lagu yang sesuai tema pembelajaran menjadi terasa sangat penting perlu dikembangkan dari aspek sisi terwujudnya lagu yang sesuai dengan isi dari materi ajar tersebut. Plummeridge (1999) pemahaman mendasar berkait dengan lagu yang perlu diketahui adalah apa yang dilihat sebagai produk tidak lebih penting dari proses karena sebuah proses berlagu akan berimplikasi pada banyak aspek termasuk aspek masuknya materi ajar dengan cara yang lebih efektif.

Pembelajaran musik yang dilakukan di Sekolah Dasar dan Sekolah Menengah Pertama sekalipun tujuannya sama sebagai alat pendidikan apresiasi dan kreasi namun pengembangan aspek materinya kadang jauh sekali berbeda. Sebagaimana yang dapat dilihat pada materi ajar musik pada jenjang Sekolah Menengah Pertama adalah berhubungan seperti teknik bernyanyi dalam bentuk tunggal dan kelompok dalam berbagai bentuk, permainan alat musik baik tunggal dan atau campuran menggunakan alat musik lokal pentatonik atau daerah dan umum diatonik, serta penggunaan musik populer yang bisa diatonik pentatonik, menunjukkan aspek materi ajar untuk Sekolah Menengah Pertama secara materi musik sudah kompleks.

Apa yang dipahami sebagai musik vokal adalah musik yang dibawakan dengan suara manusia. Musik instrumental, adalah musik yang dilagukan dengan alat-alat musik. Musik campuran, adalah perpaduan antara suara manusia dengan musik instrumental yang dihidangkan secara bersama-sama (Humpreys, 2010). Dalam karya cipta musik diatonik, biasanya melodi adalah salah satu unsur yang penting ditonjolkan (Kostek, 2005). Musik Pentatonik adalah sebuah jenis musik yang tangganadanya berintikan lima buah nada, yang susunan tangganadanya biasa dikenal dengan sebutan tangganada pelog dan slendro walau tidak selamanya demikian. Konsep-konsep yang demikian yang dilihat masih sangat wajar perlu dikembangkan pada pelaksanaan pendidikan di Sekolah.

Pembelajaran tematik yang diberikan di Sekolah Dasar oleh para guru juga menggunakan lagu-lagu diatonik dan pentatonik. Adakalanya lagu yang sudah ada dan sudah dikenal oleh para siswa sudah sesuai dengan tema pembelajaran yang harus diberikan namun lebih banyak guru harus mengganti lirik yang sesuai dengan tema pembelajaran. Baik lagu-lagu diatonik maupun pentatonik, untuk para siswa tidak masalah karena semua masuk lewat rasa. Apa yang dimaksud musik diatonis menurut Lynch (2001), dan Johnston (2002) adalah musik yang menggunakan laras musik umum atau laras musik internasional. Sedangkan apa yang dimaksud dengan musik pentatonik adalah musik yang menggunakan laras pelog dan atau slendro. Untuk anak-anak Sekolah Dasar dan Sekolah Menengah Pertama di Kota dan Kabupaten Semarang, relatif akrap atau kenal dengan musik diatonis dan pentatonis ini.

Intinya adalah materi ajar seni musik di Sekolah Dasar, sisi materinya menggunakan elemen-elemen musik seperti yang telah dikemukakan itu, seperti adanya tangganada diatonik dan pentatonik. Wujud karya musik dalam praktik pembelajarannya di sekolah selain ditujukan untuk mendapatkan pengalaman estetik siswa, melalui proses berkesenian juga diarahkan untuk menyampaikan pesan pendidikan. Penyampaian pesan pendidikan ini lebih kehubungan dengan pengolahan informasi melalui kegiatan berkesenian (Tomlinson, 2012; Plummeridge, 1999) dan itu yang dipraktekkan dalam pendidikan seni musik pada Pendidikan Dasar saat ini. 
Setiap informasi yang masuk ke dalam alat penginderaan itu sebagian ada yang diabaikan, dan ada yang masuk ke dalam alat penginderaan tanpa disadari (Lynch, 2001). Suatu karya seni selalu mengandung pesan-pesan. Pesan di sini dimengerti sebagai suatu isi, baik yang tersurat maupun yang tersirat di dalam seni tersebut (Vries, 2010: 3-4). Berhubung seni bersifat halus maka pesan apa pun yang disampaikan melalui karya seni cenderung dapat diterima dengan rasa kedamaian. Namun demikian dengan sifatnya yang halus itu, kadang menjadikan tidak setiap orang dapat menangkap pesan seni tersebut secara sama. Untuk itulah maka dalam praktik pembelajarannya, para guru tidak hanya menyampaikan lewat musik atau nyanyian namun juga masih dijelaskan dengan kata-kata, yang lagu itu oleh guru digunakan sebagai media saja untuk sekedar membantu pencapaian pembelajaran yang diinginkan oleh guru.

Pembelajaran yang efektif dan efisien bukan terletak pada aspek yang diajarkan melainkan sebagian besar karena pengaruh situasi yang diciptakan dan metode yang digunakan. Berkait dengan itulah maka seni musik atau lagu juga dipilih sebagai salah satu cara atau metode dan atau pendekatan untuk memasukkan pesan pendidikan atau materi ajar. Ini pentingnya belajar dengan seni dan belajar melalui seni. Belajar dengan seni dimaksudkan untuk menggali pengetahuan subject matter yang dipelajarinya menggunakan bantuan suatu karya seni. Belajar melalui seni, dimaksudkan untuk menggali subject matter melalui kegiatan berkesenian.

\section{Penutup}

Kebutuhan dan pengembangan materi ajar seni budaya sub materi musik untuk pendidikan dasar tingkat Sekolah Dasar dan Sekolah Menengah Pertama dikaitkan dengan kebutuhan sekolah akan pendidikan musik saat ini. Untuk Sekolah Dasar, pendidikan musik lebih diarahkan untuk pendekatan pembelajaran yang memasukkan materi ajar lewat lagu. Di sini perlu diciptakan lagu-lagu yang menopang tersampainya pesan pendidikan berdasar tema yang harus disampaikan kepada anak didik oleh sekolah atau guru. Pendidikan seni musik untuk tingkatan Sekolah Menengah Pertama lebih ke kebutuhan pengembangan materi ajar, baik vokal atau instrumental, tunggal atau kelompok, dan musik lokal daerah atau umum musik diatonis.

\section{Kepustakaan}

Bogdan, Robert, S. \& Biklen, 1982. Qualitatif Research for Education: An Introduktion to Theory and Methods. Boston: Allyn and Bacon, Inc.

Fitriani, Yulianti. 2014. "Model Pembelajaran Seni Musik melalui Lesson Study: Studi Kasus di SDN Jawilan, Serang" dalam Jurnal Resital Vol.15 No.2, Desember 2014: 126-138.

Gall, Meredith D., Joyce P. Gall, dan Walter R. Borg.1983. Educational Research An Introduction (4 ${ }^{\text {th }}$ ed.). New York: Pearxon Education, Inc.

Gegne, R.M Briggs \& Wager. 1992. Research of Deveelopment Design. New York: Holt Reinhard \& Waston.

Herminingrum, E. 2013. "Meningkatkan Aktivitas Dan Hasil Belajar Apresiasi Musik Nusantara Melalui Penggunaan Lagu Model Pada Siswa Kelas VIII A SMP Negeri 1 Pangkah, Kabupaten Tegal" dalam Jurnal Seni Musik, 2(1) Universitas Negeri Semarang.

Humphreys, Jere T. 2010. United States of

America: Reflections on the

Development and Effectiveness of

Compulsory Music Education dalam

Cox, Gordon dan Stevens, Robin

(Editor). 2010. The Origins and

Foundations of Music Education: Cross-

cultural Historical Studies in Compulsory

Schooling. London: Continuum. Hal. 121138

Johnston, Ian. 2002. Measured Tones: The Interplay of Physics and Music. Edisi kedua. London: Institute of Physics Publishing. 
Kostek, Bożena. 2005. Perception-Based Data Processing in Acoustics: Applications to Music Information Retrieval and Psychophysiology of Hearing. New York: Springer.

Lynch, Michael. 2001. Towards the abolition of 'payment by results': the end of school music or an opportunity for further development as reported in School Music Review 1892-1901?. British Journal of Music Education, 18, halaman 187-193. DOI: $\quad$ S0265051701000274. Diakses tanggal 1 Juni 2016.

Plummeridge, Charles. 1999. Aesthetic education and the practice of music teaching. Dalam British Journal of Music Education (16). Halaman 115-122.

Radika, Trias dan Totok Sumaryanto. 2013. "Upaya Meningkatkan Minat dan Hasil Belajar Membaca Notasi Musik Blok Melalui Pembelajaran Sibelius pada Siswa Kelas VII SMP Negeri 4 Ungaran" dalam Jurnal Seni Musik, 2(1) Universitas Negeri Semarang.

Rosmiati, Ana. 2014. "Teknik Stimulasi dalam Pendidikan Karakter Anak Usia Dini melalui Lirik Lagu Dolanan" dalam Jurnal Resital Vol.15 No. 1, juni 2014: 71 82.

Silverman, Marissa. 2013. A critical ethnography of democratic music listening. Dalam British Journal of Music Education, 30, hal. 725. DOI: $10.1017 /$ S0265051712000423. Diakses tanggal 7 Juni 2016.
Sumaryanto, Totok. 2002. "Pemupukan Kreativitas Anak Melalui Pembelajaran Musik" dalam Jurnal Pengetahuan dan Pemikiran Seni Harmonia Vol.2 No.3/ Januari - April 2002

Triana, Dinny Devi. "Meningkatkan Kreativitas Dalam Pembelajaran Tari Melalui Metode Proyek Pada Anak Pra-Sekolah" dalam Jurnal Pengetahuan dan Pemikiran Seni Harmonia Vol.5 No.1/ Januari-April 2005.

Tyasrinestu, Fortunata. 2014. "Lirik Musikal pada Lagu Anak Berbahasa Indonesia" dalam Jurnal Resital Vol. 15 No.2, Desember 2014: 163-168.

Utomo, Udi dan Syahrul Syah Sinaga. 2009. "Pengembangan Materi Pembelajaran Seni Musik Berbasis Seni Budaya Berkonteks Kreatif, Kecakapan Hidup, dan Menyenangkan bagi Siswa SD/MI" dalam Jurnal Harmonia, 9(2) Universitas Negeri Semarang.

Wicaksono, Herwin Yoga. 2009. "Kreativitas dalam Pembelajaran Musik" dalam Jurnal Cakrawala Pendidikan. Februari 2009 Th. XXVIII No.1.

Yoshikawa, Hiroyuki, 2012. Design Methodology for Research and Development Strategy: Realising a Sustainable Society. Center for Research and Development Strategy: Japan Science and Technology Agency. 